\title{
Thünen Elszigetelt állama: az eredeti munka ${ }^{1}$
}

\author{
Thünen's Isolated state: the original work
}

\author{
DUSEK TAMÁS
}

KULCSSZAVAK: Thünen, telephelyelmélet, mezőgazdaság, elmélettörténet

ABSZTRAKT: A regionális gazdaságtan első művelőjének tartott Thünen könyve, az Elszigetelt állam a nagy olvasatlan klasszikusok táborát gyarapítja. Thünen művének néhány oldalas másodlagos és harmadlagos értelmezései jellemzően hiányosak, nagyon jelentős mértékben tartalmilag különböznek az eredeti munkától, és sokszor ellentmondanak annak. Mindez indokolja az eredeti munkán alapuló ismertetést. A termelési és szállítási technológiában Thünen óta bekövetkezett történeti változások nem érvénytelenítik a Thünen által vizsgált tényező, a távolság gazdálkodásra gyakorolt hatását, csak a konkrét összefüggéseket módosítják és teszik bonyolultabbá. A piactól való távolság és a szállítási költségek befolyása a térhasználatra a térgazdaságtan örök érvényű alapelve marad.

Jelen tanulmány először a munka megjelenésének, különböző német nyelvü kiadásainak történeti hátterét ismerteti, majd a jelenlegi neoklasszikus fóáramú közgazdaságtantól eltérő, a tapasztalati tényeket és az elméleti igényességet egyszerre fontosnak tartó módszertanáról ír. Az elmélet feltevéseinek részletesebb tárgyalása a különböző ismertetések gyakran hiányos vagy nem létező feltevéseket tartalmazó listája miatt fontos. A szállítási költséget és a földjáradékot Thünen bonyolult levezetéssel határozza meg, de a végeredményként kapott formula könnyen értelmezhető. A körkörös termelési zónák elrendezése az általános ismertetések többnyire jól leírt részét képezi, ezért ezzel aránylag keveset foglalkozik a tanulmány. A távolság hatása az egyedi gazdaságok körül kialakuló termelési zónákra azonban a leírások mellőzött része. Thünennek az elméleti rendszer és a valóság összehasonlítására vonatkozó nagyon alapos elemzése szintén többnyire hiányzik az ismertetésekből. Ha az összehasonlításban megjelenő szempontok némelyikét megemlítik, akkor többnyire olyan módon teszik, hogy milyen tényezőkkel nem foglalkozott Thünen.

KEYWORDS: Thünen, location theory, agriculture, history of economic thought

ABSTRACT: Johann Heinrich von Thünen's classic work, the Isolated state stays in the library of the great unread books. Thünen is mostly known from secondary and tertiary interpretations, which are sometimes superficial or misleading. Thünen's the Isolated state has almost 700 pages, the most comprehensive German edition has 1260 pages, but the typical interpretation concentrates only on the first page which introduces the basic assumptions and the graphical presentation of the results. It is altogether three pages of the book, less than a three thousandth part of it. However, the methodology, the comparison of the theory and the empirics, the critical examination of the assumptions by Thünen are mostly neglected.

The aim of this contribution is the systematic reconstruction of Thünen's theory in accordance with the original work. Thünen's work is both theoretical, i.e. abstract and general,

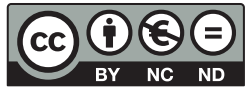


and applied, i.e. concrete, historical and descriptive. The theoretical character is attributable to the systematic and general examination of the influencing factors of land use. Since these factors are general and eternal categories of human economic activity, which are independent from the historical time and actual geographical space, the theory is applicable always and everywhere. Only the context, the actual manifestation of these general categories will be different in different times and spaces: transport costs, production technology, products, climatic circumstances, relative prices and so on.

Thünen was aware of the fact, that his model is an idealisation of the agricultural landuse pattern: "The abstraction from reality without which we cannot come to any scientific knowledge has several dangers, namely: (1) We separate in thought what is in fact mutually interrelated. (2) Our conclusions rest upon assumptions of which we are not clearly conscious and which we therefore do not make expressly, and we then consider as generally true what is true only under these specific assumptions. The history of economics gives us many striking examples." (Thünen 1930, 407-408.) He examines thoroughly the differences between his idealisation and reality.

\section{Bevezetés}

A tudományos tudás felhalmozódásáról vallott egyfajta elképzelés szerint a kortárs publikációkba a korábbi generációk által elért minden eredmény beépült. Így az elmélettörténeti érdeklődést, valamint a meghaladott, hibásnak bizonyult elméletekből való tanulás szándékát leszámítva felesleges a korábbi munkák tanulmányozása. Az idő szűkösségére tekintettel is elegendő lenne napjaink és az elmúlt 5-10 év tudományos termésének az ismerete ahhoz, hogy minden szempontból teljes és a legmagasabb szintű ismeretünk legyen a tudomány eredményeiről. A tankönyvekből az elfogadott, megszilárdult, bizonyított tudásanyagot lehet elsajátítani, a friss monográfiák az elmúlt néhány év újabb eredményeit foglalják össze, a szakfolyóiratok az aktuális kutatási témákról közölnek tanulmányokat. Vagyis a szakfolyóiratok tanulmányai révén lehet a legjobban tisztában lenni a legújabb tudományos trendekkel, legmodernebb, legfejlettebb elképzelésekkel, módszerekkel. A 20-30 éve megjelent tanulmányokat már bizonyosan meghaladta, de legalábbis tökéletesítette a tudomány. Az elavult, megcáfolt, hibásnak tartott elméletekkel azért sem érdemes túl sokat foglalkozni, mert az a legújabb fejleményekben való tájékozatlanság látszatát keltheti.

Ez a történelemellenesnek nevezhető mentalitás talán alkalmazható a matematikában, ahol a tankönyvek a huszadik századig felhalmozódott matematikai ismereteket letisztultan, az eredeti felfedezés tárgyalásához képest könnyebben érthető formában tartalmazzák. Az elméleti közgazdaságtanban is ezt a mintát követik egyes szerzők, amennyiben a kortársakra való hivatkozások mellett egészen ritkák a már nem aktív szerzőkre és azok elméleteire történő hivatkozások. Az utóbbiak esetében is sokszor az aktuális tankönyvi vagy szakfolyóirati értelmezés a hivatkozás tárgya, nem az eredeti mü. Doktori értekezéseket, de az aktuális elmélettörténeti írások révén még a közgazdaságtan egész történetét is meg lehet írni anélkül, hogy érdemben foglalkoznának 10 
évnél régebbi munkákkal. Amikor 1966-ban a telephelyelmélet első klasszikusa, Thünen kötetének megjelent az angol fordítása, volt, aki azt írta, hogy a fordításnak csekély az értéke, csak a közgazdasági gondolatok és a mezőgazdaság története iránt érdeklődők számára érdekes, mert Thünen gondolatai napjainkban sokkal könnyebben közölhetők a grafikus ábrázolások segítségével, mint Thünen nehezen értheto", homályos algebrai kifejezésmódjával és a költségek részben pénzben, részben gabonában történő furcsa mérésével (Peters 1967, 194.).

Ennek a nézetnek az ellenpontjában álló másik szélsőséges vélemény szerint a korábbi szerzők már minden lényeges gondolatot leírtak. A kortárs munkák vagy az alkalmazott kutatások révén tudnak hozzájárulni a közgazdasági gondolatok szinten tartásához, vagy a korábbi munkák hiperfinom részleteinek további kimunkálásával. Ez alapján minden, a mezőgazdasági telephelyelmélettel kapcsolatos alapvetö gondolat valamilyen formában megtalálható Thünennél. Ennek a megközelítésnek a domináns történelemellenes mentalitással szemben nincsen tömegbázisa.

Véleményem szerint a történelemellenes nézet helyes volta tapasztalati kérdésként úgy dönthető el, ha elolvassuk az eredeti klasszikus műveket és összehasonlítjuk a későbbi értelmezéseikkel, megvizsgáljuk az értelmezéseken belül összhangot, valamint az ugyanazt a kérdést tárgyaló elméleteket. Erre vállalkozom Thünen Elszigetelt állam címü könyve kapcsán két önálló, de egymással összefüggő tanulmányban. Ebben az írásban Thünen eredeti művének megítélésem szerint lényegesebb elméleti részeit rekonstruálom, nem szorítkozva a jól ismert Thünen-körökre. A másikban a későbbiekben Thünen értelmezéseivel foglalkozom, remélhetőleg eloszlatva az elmélete körüli félreértéseket. Bár jelen tanulmányban is utalok valamennyire a Thünennel kapcsolatos másodlagos és harmadlagos irodalmakra és az eredeti munka modern értelmezéseire, de ezzel alaposabban a másik tanulmányban foglalkozom majd. Thünen gondolatainak saját kora elméleteihez való viszonyáról munkája úttörő jellege miatt nem írok, leszámítva a járadékelméletet.

A tanulmány szerkezete a következő. Először a munka megjelenésének, különböző német nyelvű kiadásainak történeti hátterét ismertetem. Ezt követően a módszertanáról írok, majd a kötet jól ismert első két oldalát mutatom be. Az elmélet feltevéseinek részletesebb tárgyalását indokolja a különböző későbbi ismertetések gyakran hiányos, nem létező feltevéseket tartalmazó vagy megtévesztő listája Thünen állítólagos feltevéseiről. A szállítási költséget és a földjáradékot Thünen bonyolult levezetéssel határozza meg, de a végeredményként kapott formula könnyen értelmezhető. A körkörös termelési zónák elrendezése az általános ismertetések többnyire jól leírt részét képezi, ezért ezzel aránylag keveset foglalkozom. A következő téma, a távolságnak az egyedi gazdaságok körül kialakuló termelési zónákra gyakorolt hatása azonban a leírások mellőzött része. Thünennek az elméleti rendszer és a valóság összehasonlítására vonatkozó nagyon alapos elemzése általában szintén hiányzik az ismertetésekből. Ha az összehasonlításban megjelenő szempontok némelyikét megemlítik, akkor több- 
nyire olyan módon teszik, hogy milyen tényezőkkel nem foglalkozott Thünen. Azt tapasztaltam, hogy Thünen műve módszertanilag és tartalmilag meghaladja nemcsak a tipikus értelmezések színvonalát, hanem a kortárs földhasználati elméletek nagy részét is, az utóbbiakét részletezettségben és alaposságban is. Ez pontosan a fordítottja az első bekezdésben a tudás felhalmozódásáról vázolt folyamatnak.

\section{Az Elszigetelt állam írásának és megjelenésének körülményei}

Thünen régi szabad fríz földbirtokos nemzetség sarjaként született 1783-ban a kelet-frízföldi szülői udvarházban, Canarienhausenben. Középiskolai tanulmányai során elméleti és gyakorlati mezőgazdasági képzésben is részesült. 1803-ban kezdte meg egyetemi tanulmányait Göttingában. 1804 őszén „végzetesnek” bizonyult tanulmányi látogatást tett Mecklenburgban, ahol beleszeretett iskolatársa lánytestvérébe, Helena Berlinbe. Egyetemi tanulmányainak a szerelem véget vetett, így egyetemi végzettséget sohasem szerzett. Ez, valamint a nyelvvizsgák hiánya elmélyült későbbi kutatómunkájában egyáltalán nem akadályozta. A napóleoni háborúk miatt a házasságra csak 1806 januárjában kerülhetett sor. A háborúk zavaros éveit követően Thünen 1810-ben 65 ezer tallérért megvásárolta a Rostocktól 37 kilométerre fekvő tellowi birtokot, ahol egy mintagazdaságot fejlesztett ki. A gazdaság tevékenységének legkisebb részleteiről is már a kezdetektől gondos nyilvántartásokat vezetett, amelyek későbbi könyvének tapasztalati adatait szolgáltatták. (Petersen 1944, 5-7.; Waentig 1930, III-IV.)

1820-ra elegendő gazdálkodási adatot gyüjtött össze az Elszigetelt állam írásához. A könyvet becsvágy és ambíció hiányában barátai unszolására adta ki 1826-ban Hamburgban. A mủ honoráriumaként 78 tallérban részesült 400 példány értékesítését követően (Waentig 1930, VI.). A könyv teljes német címe így szól: Der isolierte Staat in Beziehung auf Landwirtschaft und Nationalökonomie, vagyis Az elszigetelt állam mezögazdasági és nemzetgazdasági kérdései. Az első kiadás alcíme: Untersuchungen über den Einfluß, den die Getreidepreise, der Reichtum des Bodens und die Abgaben auf den Ackerbau ausüben, azaz Vizsgálódások a gabonaárak, a föld termékenysége és az adók szántóföldi gazdálkodásra gyakorolt befolyásáról. Az alcím nem fejezi ki hűen a könyv rendkívüli gondolatgazdagságát. A kötet három nagyobb részre tagolódik: az elszigetelt állam felépítése, az elszigetelt állam és a valóság összehasonlítása, az adók hatása a szántóföldi művelésre. Az alcímek annyiban megtévesztők, hogy Thünen egyfolytában foglalkozik elmélete és a valóság összehasonlításával, valamint az adók hatását vizsgálja korábban is. A mü átütő sikert aratott, a Rostocki Egyetem a közhangulatot fejezte ki azzal, hogy 1830-ban Thünennek tiszteletbeli doktori címet adományozott (Waentig 1930, VI.).

A könyv második, bővített kiadása 1842-ben jelent meg. 1850-ben adták ki új kötetben a könyv második részét, amelynek alcíme: Der naturgemäße Arbeitslohn und dessen Verhältnis zum Zinsfluss und zur Landrente, vagyis A munkabér természe- 
tes nagysága és kapcsolata a kamatlábbal és a földjáradékkal. Ezt a kiadást a még abban az évben elhunyt Thünen felügyelte. A második kötet a jövedelemeloszlást tárgyalja, de térbeli kérdésekkel is foglalkozik, föleg a 34 oldalas bevezetőben, amely az első kötet módszerét és főbb megállapításait tekinti át, valamint szétszórtan a későbbi fejezetekben. Az eredeti első és második kötetet egy kötetben adták ki 1910-ben, 1921-ben és 1930-ban. Ez a már nem gót betűs kiadás oldalszámozásban eltér egy kicsit az 1842-ben és 1850-ben megjelent kiadásoktól, de a margón közli a korábbi kiadások oldalszámait. Ismertetésemben terjedelmi okokból csak ezzel, az Otto Waenting bevezetőjével megjelent egykötetes, összesen 678 oldalas kiadással foglalkozom.

A könyv harmadik kiadása négy kötetben jelent meg 1875-ben, a Thünent személyesen ismerő, a tellowi birtokon Thünennél mezőgazdasági tanuló Hans Schumacher gondozásában. Első és második kötete megegyezik az 1842-es és 1850-es kiadással. A harmadik, 440 oldalas és a negyedik, 144 oldalas kötetet Thünen életében megjelent rövidebb írásaiból és hátrahagyott feljegyzéseiből állította össze Schumacher. A harmadik kötetet az 1850-es második kötet második részeként alcímezte Schumacher, a negyedik kötet alcíme: Grundsätze zur Bestimmung der Bodenrente, der vorteilhaftesten Umtriebszeit und des Werths der Holzbestände von verschiedenen Alter für Kiefernwaldungen, vagyis A földjáradék, a legelőnyösebb nevelési idő és a fakészlet értéke meghatározásának alapelvei a különféle fenyőerdőknél. Ebben a két kötetben olyan térbeli kérdésekkel foglalkozik Thünen, mint a települések eloszlása, a népsürüség, az ipari agglomerációk kialakulása, a vasút és a közlekedés szerepe.

Az Elszigetelt állam második kötetének fordítása 1960-ban jelent meg angolul. Az 1966-ban Peter Hall szerkesztésében kiadott angol fordítás az első kötetet tartalmazza, valamint kivonatokat a további részekből. ${ }^{2}$

Az elszigetelt állam Thünen életében megjelent részei így összesen csaknem 700 oldalt tesznek ki, a Schumacher-féle változat 1260 oldalt. Nemcsak a könyv hosszúsága, hanem rendkívüli gondolatgazdagsága is lehetetlenné teszi, hogy egyetlen áttekintő tanulmány minden lényeges részére kitérjen. A tipikus ismertetések ugyanakkor a mü kevesebb mint fél százalékára, három oldalra korlátozódnak: az első két oldalra és a 387. oldal ábrájára.

\section{Az Elszigetelt állam célja és módszertana}

Minden gazdasági elmélet során meg kell határozni, hogy milyen tényezőket tekintünk külső adottságnak (exogén tényezőknek) és az elmélet által meghatározandó (endogén) tényezőnek. Az endogén tényezők száma alapján az egyetlen endogén tényezőt tartalmazó elméletektől elindulva egyre több és több endogén tényezőt tartalmazó skálán haladhatunk, de a skála végpontja nem határozható meg egyértelmüen, mert nincsen olyan elmélet, amely minden lehetséges té- 
nyezőt endogenizálna. Az egyetlen endogén tényezős elméleteket parciális elméleteknek, a sok endogén tényezőt tartalmazó elméleteket általános elméleteknek is nevezik. Ez az elnevezés azonban megtévesztő. Az endogén tényezők számának növekedésével többnyire egyszerre növekszik is és csökken is az elmélet általánossága. Ennek az az oka, hogy az endogén változók számának növelésével növekszik az endogén változók közötti kapcsolatok komplexitása. Az elmélet átláthatósága ezért egyre több leegyszerűsíto feltevés bevezetését követeli meg, amelyek megnyilvánulhatnak az exogén változók leegyszerüsített kezelésében és az exogén és az endogén változók közötti kapcsolatok, valamint az endogén változókon belüli kapcsolatok kezelésében. A kezelhetőség érdekében bevezetett leegyszerűsítő feltevések csökkentik az elmélet általánosságát, alkalmazhatóságát, valóságérvényét, tapasztalati ellenőrizhetőségét. Ez jól megfigyelhető az egyedi vállalkozás optimális elhelyezkedését leíró elméletek (az összes többi vállalkozás elhelyezkedése ekkor külső adottság) és az „összes” vállalkozás egymással összefüggő módon meghatározandó általános egyensúlyi elhelyezkedését leíró elméletek összehasonlításával. Mindezek miatt nem osztom azt a véleményt, miszerint az endogén tényezők nagyobb számával szükségszerüen a gazdasági jelenségek magasabb rendű elméleti magyarázata adható.

Thünen elmélete a földterület optimális hasznosításával foglalkozik, ahol a térhasználat mikéntje az elsődleges endogén változó. Az elmélet a térhasználattal kapcsolatosan legalább három, egymással összefüggő jelenségre ad magyarázatot:

1. A föld bérleti díjának, a földjáradéknak a nagysága hogyan alakul a különféle befolyásoló tényezők hatására.

2. Az egyes földterületek művelési ága hogyan alakul.

3. Adott művelési ágon belül milyen intenzitású a termelés.

A főbb kérdéseken kívül Thünen rendkívül sok további kérdést vizsgál, amelyek egy részére később kitérek. Az elmélet szerint a döntéshozó az egyéni gazdálkodó, aki valamennyi parcellán minden egyes termény összes lehetséges intenzitású termelésére vonatkozóan összehasonlítja az elérhető földjáradék nagyságát, és ez alapján dönt a maximális földjáradékot eredményező termény és intenzitás mellett. Egy parcellán csak egyféle terményt lehet termelni, a termékek egymással versenyeznek minden egyes parcellán azért, hogy melyiküket termeljék ott. Adott terményt többféle módon, így eltérő intenzitással lehet termelni, vagyis a termelési módok is versenyeznek egymással. A versenyt az a termék és termelési mód nyeri meg, amely a legnagyobb földjáradékot eredményezi. A terményenként figyelembe vett főbb változók és a közöttük lévő elsődleges kapcsolatok az 1. ábrán láthatók. Az ábra hiányos abból a szempontból, hogy csak a kapcsolatok elsődleges irányait mutatja, pedig az egyes tényezők valójában kölcsönösen összefüggnek egymással. A termelés intenzitása például visszahat a szállítási költségre, de a két tényező közül a szállítási költség jelenti az oksági kapcsolat kiinduló pontját, mert azt kevésbé lehet befolyásolni, mint a termelési módot. Bár a termékek piaci ára az elmélet szempontjából külső adottság, azok ára is függ valamennyi felsorolt tényezőtől. 
1. ábra: A terményenként figyelembe vett alapvető tényezők közötti elsődleges kapcsolatok Thünen elméletében

Primary connections among the basic factors of Thünen's theory

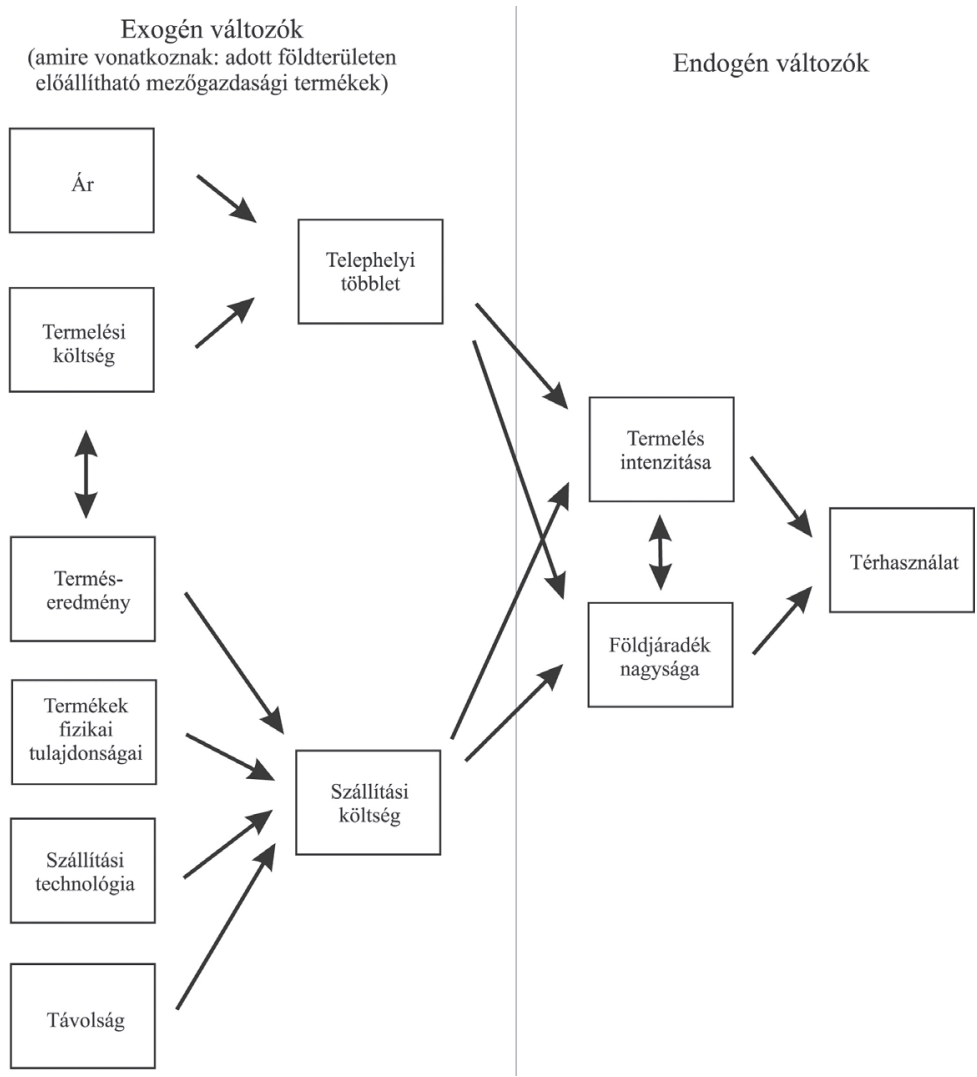

Forrás: saját szerkesztés.

Az elmélet endogén változója egyrészt a földjáradék nagysága, amely kölcsönösen függ a másik endogén változótól, a termelés intenzitásától, harmadrészt pedig ez a két endogén változó meghatározza a földhasználat mikéntjét. $\mathrm{Az}$ az értelmezés indokolatlan, miszerint a térbeliség endogén kezelése az új gazdaságföldrajzzal jelent volna meg a gazdaságelméletben, mivel az már a történetileg legelső explicit telephelyelméletben is endogén volt, csakúgy, mint a későbbi elméletekben. ${ }^{3}$

Thünen munkája egyszerre elméleti (általános, absztrakt, törvénykereső) és alkalmazott (konkrét, történeti, leíró) jellegü. Az elméleti jelleg a földhasználatot befolyásoló tényezők szisztematikus és általános vizsgálatában nyilvánul meg. Mivel a figyelembe vett tényezők az emberi gazdálkodás általános, mindig és mindenhol előforduló kategóriái, ezért következtetései valamennyi történelmi korszakban, valamennyi gazdasági és társadalmi rendszerben érvényesek és 
alkalmazhatók a mezőgazdasági térhasználat leírására és magyarázatára. Ami változik történetileg (például a 19. század eleji és a 21. század elejei Mecklenburgban) és térbelileg (például a 21. század elejei Mecklenburg és Ghána között), az a figyelembe vett tényezők kontextusa, konkrét történelmi megnyilvánulása: a szállítóeszközök, a termelési technológia, a termények, a klimatikus viszonyok, az árarányok stb.

A könyv alkalmazott részeinek adatai elsősorban Thünen saját, 70000 mecklenburgi négyzetvessző nagyságú tellowi gazdaságának többéves, Thünen által vezetett részletes nyilvántartásaiból származnak, de hivatkozik németalföldi, angol és más térségek mezőgazdaságára vonatkozó megfigyelésekre is. Az elméleti és általános rész nem különül el a könyvön belül és az egyes fejezeteken belül sem.

Az írás sajátossága, hogy Thünen az árakat (a szállítási költség és a földjáradék nagyságát) kettős egységben, pénzben (tallérban) és rozsban határozza meg, majd a számítások végén váltja át a rozst tallérra. Az átváltási arány a várostól való távolságtól függ. A pénz a vidéken fogyasztott városi javak, a rozs a farm által megtermelt javak kifejezési eszköze. Az egyéb mértékegységek közül a mecklenburgi vessző 4,66 métert tesz ki, így 70000 négyzetvessző 152 hektárral egyenlő. ${ }^{4} \mathrm{~A}$ számos, Thünen által használt nem metrikus hossz-, terület- és térfogatmérték közül a fontosabbak az 1. táblázatban láthatók.

Thünen világosan megkülönbözteti az elmélet általánosan érvényes, verbálisan kifejezett absztrakt formáját és a konkrét, történetileg érvényes, tellowi birtoka gazdálkodása alapján megfigyelt adatokkal alátámasztott megjelenési formáját. Thünen így ír a kérdésről: „Ha valaki egy másik birtokot - amely a tellowi birtokhoz nem hasonló - vizsgál, amelynek a munkaköltségeit, a termékek termelési költségeit, a föld bérleti díját stb. a valóságból vett adatok alapján számolja, és aztán az előbbi megállapítások alapján és az itt megfigyelt módszerekkel a számításokat véghezviszi és azokból következtetéseket von le, akkor a kétféle vizsgálat összehasonlításából azt figyelhetnénk meg, hogy a számítások teljesen más számokhoz vezethetnének; de azt találhatnánk, hogy a végeredmények és következtetések között, ha ezeket szavakkal mondjuk ki, ismét tökéletes összhang uralkodna." (Thünen 1930, 47.) Majd később úgy folytatja, hogy nem érné meg a fáradságot az egyszerü, ésszerü következtetésekkel könnyen belátható eredményeket hosszas számítgatásokkal bizonyítani, ha mindezek a szá-

1. táblázat: Az Elszigetelt állam leggyakrabban használt mértékegységei Prevailing units of measurement in the Isolated state

\begin{tabular}{lll}
\hline & Megnevezés & Metrikus egység \\
\hline Hosszúság & Mecklenburgi vessző (Rute) & $4,66 \mathrm{~m}$ \\
& Német mérföld (Meile) & $7532 \mathrm{~m}$ \\
\hline Terület & Négyzetvessző (ロRute) & $21,7 \mathrm{~m}^{2}$ \\
\hline Térfogat & Berlini véka (Berliner Scheffel) & 54,9611 \\
& & nagyjából $40 \mathrm{~kg}$ rozs \\
\hline
\end{tabular}

Forrás: saját szerkesztés a http://www.emecklenburg.de/Mecklenburg/l15.php?messen alapján. 
mítások nem mutatnák be magát a módszert is (Thünen 1930, 51.). Thünen szerint az elszigetelt állam a valóságon alapuló vizsgálatként egy olyan képszerủ ábrázolás, amely megkönnyíti a helyzet áttekintését (Thünen 1930, 30-31.). Az elmélet olyan tükröt állít fel, amely a valóság bonyolult, kusza, egymást keresztező vonalait tiszta perspektívában engedi meg láttatni (Thünen 1930, 31.). A tapasztalat egy biztos pontja, egyetlen birtok lesz tudományos magasságokba emelve azáltal, hogy az általános törvényeket bizonyítjuk segítségével. (Thünen 1930, 31.).

Thünen késóbb is több helyen foglalkozik azzal a kérdéssel, hogy egyetlen gazdálkodási egység adatai mennyiben teszik lehetővé az eredmények általánosítását. „Nyilvánvaló, hogy ezek a számítások már a szomszédos birtokon sem adnának teljesen azonos eredményt, még kevésbé hasonlítanának a még messzebb fekvő birtokokra, egy más égöv alatt, más nemzeti karakterü munkásokkal." (Thünen 1930, 44-45.) Ha nem lehetne általánosítani - folytatja Thünen -, az ahhoz hasonló helyzetet jelentene, mint ha minden egyes gazdálkodónak, aki új helyen kezd el gazdálkodni, a nulláról kellene újra megtanulnia az egész gazdálkodási folyamatot és nem tudná felhasználni korábbi tapasztalatait. A távolság és a szállítási költségek mindenhol befolyásolják a gazdálkodást, és az ilyen mindenhol és mindig érvényesülő tényezők képezik a kutatás tárgyát (Thünen 1930, 45.). Ugyanakkor végső soron, véleményem szerint, bár fontos a konkrét tapasztalati adatok és az elmélet összhangja, nem ez a döntő tényező az elmélet érvényességének elfogadásakor, hanem az elmélet összes állítása közötti összhang; az elmélet egyedi állításainak a tapasztalattal való összekapcsolhatósága alapján, mindezen szempontok szerint együttesen lehet dönteni az elméletről.

Thünen teljes mértékben tisztában volt azzal, hogy elmélete idealizáció, amely a valóságot nem a konkrét részletek szerint írja le, hanem a leírni kívánt jelenséget idealisztikus formában közelíti a valóság néhány lényeges elemét változónak kiválasztva. A változónak kiválasztott lényeges elemek a távolság, szállítási költség és a termékek minőségi, súlybeli különbségei. A kevésbé lényeges elemek - mint a föld minősége, a termékek piaci ára és további, később felsorolt elemek - hatását úgy vizsgálja, hogy kiválasztja egyiküket és bemutatja az eredményekre gyakorolt módosító hatást.

Nemcsak a könyv címe, hanem módszertana miatt is érdekes adalék, hogy a Thünen-archívumban kezelt eredeti Thünen-feljegyzések szerint 1819-ben Thünen még nem izolált, hanem ideális állam címet tervezett, és végül féltestvére javaslatára választotta az izolált jelzőt. Az izoláció így kettős értelmü: konkrétan az állam külvilágtól való elzártságát jelenti, módszertani értelemben pedig az egyes tényezőknek a rendkívül komplex valóságra gyakorolt hatásának elszigetelt vizsgálatát. Az ideális állam nem egy utópikus értelmű vagy tökéletes államot jelentett volna, hanem a konkrét, egyedi részletektől eltekintő, absztrakt megközelítéssel vizsgált államot (Petersen 1944, 27-28.).

A valós gazdasági adatok intenzív használata miatt Schumpeter $(1954,466$. Thünent az ökonometria egyik védőszentjének nevezte. Mivel az ökonometrikus megnevezést, illetve jelzőt később számos szerző átvette (így Fujita 2011; 
Melamid 1955; Samuelson 1983), indokolt megemlíteni napjaink ökonometriájának és Thünen módszertanának lényeges különbségeit. Először is, Thünen saját maga által gyüjtött és megfigyelt adatokat használt fel az elemzéshez, míg napjaink ökonometriai elemzéseinél gyakran olyan gazdaságstatisztikai adatokat használnak, amelyek pontos minősége és tartalma az adatgyüjtés komplexitása miatt nem határozható meg. Másodszor, Thünen determinisztikus függvénykapcsolatokat fejezett ki a mért változók között, de egyetlen regressziószámítást, egyetlen homoszkedaszticitási tesztet vagy szignifikanciavizsgálatot sem végzett. Az adatokat nem sztochasztikus folyamatot leíró eredményeknek tekintette, hanem azoknak, amelyek ténylegesen voltak: egy történeti helyzet adekvát leírásához használható tényeknek, amelyekkel kapcsolatban ismeretelméletileg nem is lenne indokolt semmilyen valószínüségi becslést adni. Mindemellett, mint írtam, tisztában volt a számítások esetlegességével, időhöz és helyhez kötött érvényességével. Thünent ökonometrikusnak tartani tehát legfeljebb az ökonometria eredeti értelmében, az absztrakt gazdasági törvények gazdaságstatisztikai adatokon nyugvó numerikus igazolása/illusztrálása értelmében lehet.

\section{Az Elszigetelt állam első két oldala}

Thünen könyvének első oldala a kiindulópontokat, más szóval az alapfeltevéseket mutatja be, második oldala magát az elméletet írja le főbb vonalaiban. Ezek közismertek az ismertetésekből, maga a könyv viszont nem jelent meg magyarul, ezért itt az első két oldal fordítását közlöm:

„Képzeljünk el egy hajózható folyó és csatorna nélküli termékeny síkság közepén fekvő nagyon nagy várost. A síkság egyenletes minőségü, mindenhol művelhető termékeny földdel rendelkezik. A várostól nagy távolságra a síkság egy megmüveletlen vadonban végződik, amellyel a város a világ többi részétől teljesen el van szigetelve.

A síkságon nincsen más város az egy nagyvároson kívül, amelynek minden kézmüves termékkel el kell látnia a vidéket, úgy, mint ahogy a város egyedül a környező vidéktől szerzi be minden élelemszükségletét.

A bányák és sólepárlók, amelyek fémekkel és sóval látják el az egész várost, a központi város közelében fekszenek, amelyet, mivel az egyetlen, ezentúl egyszerüen a városnak nevezhetünk." (Thünen 1930,11.)

Ezen feltevések ismertetését követően Thünen megfogalmazza az elméleti feladatot:

„Felvetődik a következő kérdés: ezen körülmények mellett milyen szántóföldi termelés alakul ki, és a várostól való nagyobb és kisebb távolság milyen hatást gyakorol a mezőgazdaságra, amennyiben az a legnagyobb konzekvenciával művelt." (Thünen 1930, 12.) Ezt követően Thünen meg is előlegezi a könyvében tovább részletezett és finomított választ: 
„Egészen világos, hogy a város közelében olyan termékeket kell termeszteni, amelyeknek értékükhöz képest nagy a súlyuk vagy a térfogatuk, és amelyeknek ezért a városba való szállítási költsége olyan jelentős, hogy nagyobb távolságról már nem lehetne beszállítani; ugyanígy a gyorsan romló és ezért frissen fogyasztandó termékeket. A várostól távolodva azonban egyre inkább azokat a termékeket termelik, amelyek értékükhöz képest alacsony szállítási költséget igényelnek.

Egyedül ezen okokból a város körül elég éles koncentrikus körzetek képződnek, mindegyik a maga legfontosabb terményével.” (Thünen 1930,12.)

\section{Az elmélet feltevéseiről}

Egy elmélet állításokból és az állításokból kiinduló, a logikai szabályokat betartó következtetések rendszeréből áll. Az elmélet kiindulópontjaként szolgáló állításokat többnyire feltevéseknek hívják, a nyilvánvalóan elfogadható állításokat axiómáknak, esetleg posztulátumoknak. A feltevéseknek egymással konzisztenseknek kell lenniük. Például egy térbeli modellnél a szállitási költség létezése (egy valósággal összhangban lévő feltevés) és a térbelileg azonos árak feltevése (egy valós helyzettel ellentétes feltevés) egymással nem konzisztensek. A következtetéseket tételeknek, törvényeknek vagy szabályoknak is nevezik, az elméletre a modell kifejezést is használják. A tudomány egészében nem beszélhetünk a nyelvhasználat egységes gyakorlatáról, de ez az elméleten belüli következetes szóhasználat mellett nem jelent tényleges tartalmi problémát és nem vezet a megértés nyelvhasználatból fakadó nehézségeihez. Ha egy elméleten belül használják a különféle terminusokat, akkor megkülönböztethetik egymástól a jelentésüket, jelentésárnyalatukat.

Mindezen nyelvhasználati kérdések tárgyalását a feltevések szerepéről a kortárs neoklasszikus főáramban uralkodó zavar indokolja. Ez alapján „az egyszerüsíto feltevésekben semmi rossz nincs - ellenkezőleg, csak átütő egyszerüsítések révén remélhetjük, hogy értelmet találunk a valóságos világ zavarba ejtő összetettségében." (Krugman 2003, 16.) Ezen nézet hiányossága abban rejlik, hogy nem tesz különbséget a feltevések különböző típusai között és megfeledkezik annak vizsgálatáról, hogy a feltevések milyen hatást gyakorolnak az elméletek alkalmazhatóságára. Thünen nem esett ebbe a hibába, mivel így ír az idealizáció veszélyeiről:

„A valóságtól való elvonatkoztatás (absztrakció), amely nélkül nem lehetséges tudományos ismeretekhez jutni, kétféle veszélyt rejt magában, nevezetesen:

1. gondolatban szétválasztunk olyan tényezőket, amelyek a gyakorlatban kölcsönösen hatnak egymásra, és

2. a következtetéseink olyan előfeltevéseken nyugszanak, amelyeknek teljesen világosan nem vagyunk a tudatában, és ezért nem fejezzük ki őket, amiért általánosan érvényesnek tartjuk azt, ami csak ezen előfeltevések fennállása esetén érvényes. 
A közgazdaságtan története számos példát szolgáltat minderre." (Thünen 1930, 407-408.)

A modell érvényessége tehát az előfeltevések valóságérvényén múlik. Thünen feltevéseinek a térhasználatra gyakorolt hatását maga vizsgálta meg. Ezzel szemben a neoklasszikusok gyakorlata alapján bármilyen irreális feltevés használata anélkül engedélyezett, hogy a feltevéseknek az elmélet gyakorlati alkalmazhatóságára való hatását, a feltevés és a tényleges helyzet közötti kapcsolatot megvizsgálnák.

A feltevések között megkülönböztethetjük a valós helyzettel összhangban lévő, de konkrétan nem részletezett feltevéseket, az elméleti leírást segítő, átmenetileg korlátozó feltevéseket, az elhanyagolható tényező típusú feltevéseket és az elmélet hatókörét korlátozó feltevéseket. Thünen egyetlen feltevése sem korlátozó jellegü, ezért feltevések helyett a következő lista elemeit lehetne olyan tényezőknek vagy kiindulópontoknak nevezni, amelyek az alapmodell felépítéséhez használatosak, de amelyeknek térhasználatra gyakorolt hatását később Thünen megvizsgálta. Ezen feltevések térre vonatkozó részét a könyv első oldalán vezeti be Thünen, a továbbiakat a későbbi tárgyalás során szétszórtan találhatjuk. Az alábbi ismertetés a teljes könyvön alapul, zárójelben a feltevés első előfordulásának oldalszáma látható.

A. A térre vonatkozófeltevések

1. A földterület sík, nincsenek hegyek. (11. o.)

2. Nincsen hajózható folyó vagy csatorna. (11. o.)

3. A talaj homogén, azonos termelékenységü és mindenhol alkalmas a földművelésre. (11. o.)

4. A klíma mindenhol egyforma. ${ }^{5}(424$. o.)

5. A földterület közepén egy város található. (11. o.)

6. A földterület széle megműveletlen pusztaság, amely teljesen elszigeteli a várost a külvilágtól. (11. o.)

7. Nincsen más város a síkságon. (11. o.)

8. A mezőgazdasági termelők a síkságon szétszórva találhatók, akik terményeiket közvetlenül értékesítik a város egyetlen piacán. (15. o.)

9. A termelők és fogyasztók közötti kapcsolat csak a város piacán lehetséges (a kereslet egy pontban összpontosul). (15. o.)

B. A szállitásra vonatkozó feltevések

1. A szállítás ló vontatta szekerekkel történik. (15. o.)

2. A termékek súlyukhoz, térfogatukhoz és árukhoz viszonyított szállítási költsége eltérő. (12. o.)

3. A szállítási költséget a farmerek fizetik. (16. o.)

C. Gazdaságifeltevések

1. A piaci ár a városi piac külső adottságaként rögzített. (16. o.)

2. Az ipari termelés a városban zajlik. (266. o.)

3. Az állati termékek és a rozs áraránya a tér minden pontján azonos. (37. o.) 
4. Nincsenek adók. (A 328. oldalon megemlíti, hogy az addigi elemzésben az adóktól elvonatkoztatott.)

D. Viselkedési feltevés

1. A gazdasági szereplők konzekvensek. (12. o.)

Az elmélet modern ismertetései megdöbbentően nagy számban tartalmaznak Thünennél egyáltalán nem, implicit módon sem található feltevéseket, amelyek sokszor egymással vagy az elmélet következtetéseivel is összeegyeztethetetlenek. Az összesen 17 feltevés a 2. táblázatban látható módon tipizálható, ebben külön típusba soroltam a részben a valósággal összhangban lévő, részben átmenetileg korlátozó, a leírást segítő feltevések közé tartozó viselkedési feltevést. A viselkedési feltevés a gazdálkodókra vonatkozik, és nem a háztartásokra vagy fogyasztókra. Valamilyen viselkedési feltevés nélkül lehetetlen lenne bármilyen gazdaságelmélet megalkotása. Ha nem konzekvens viselkedést feltételeznénk, hanem véletlenszerüt vagy kaotikust, akkor semmilyen elméleti előrejelzést nem lehetne adni a gazdaság működéséről, az emberek bárhogyan viselkedhetnének, bármilyen térbeli mintázat elképzelhető lenne. Thünen viselkedési feltevésének értelmes voltát bizonyítja az elméletével összhangban lévő számos tapasztalati megfigyelés. Arra azonban a tárgyalás során többször utal, hogy a valóságban nem mindig konzekvensen viselkednek a gazdálkodók, ami a valóságnak az elméleti idealizációtól való eltéréséhez vezethet.

A szállításra vonatkozó első feltevés Thünen idejében összhangban volt a valósággal. A későbbi kritika elég nagy része vonatkozik erre a feltevésre, ami két okból sem jogos, egyrészt mert ő nem gondolhatott még például a légi szállítás szerepére, másrészt később megvizsgálja a vízi szállítás és a vasúti szállítás lehetőségét is. Így a kérdéssel azért indokolt foglalkozni az elmélet minden történeti megnyilvánulási formájának elemzésekor, mert a szállítás kontextusának történeti változásai és területi eltérései (például a trópusokon sem jellemzőek a ló vontatta szekerek) lényegesen befolyásolják a térhasználat aktuális képét. A szállítási költség akkor is és ma is függött a termékek súlyától és térfogatától, ez tehát ismét lényeges és a valósággal összhangban lévő feltevés.

A feltevések között egymással nem összeegyeztethető a B2 és a C3, mivel a termékenkénti eltérő szállítási költségek eltérő helyi árarányokat eredményeznének. Az árarányok térbeli változatlanságának feltevésére azért volt szükség, mert e nélkül az állati termékek nem lettek volna általánosságban rozsban kifejezhetők, ami nehézzé tette volna a földjáradék kiszámítását a hétéves vetés-

2. táblázat: Thünen elmélete feltevéseinek típusai

Types of assumptions in Thünen's theory

\begin{tabular}{ll}
\hline A gazdaságelmélet alapfeltevése & D1 \\
Valósággal összhangban lévő feltevés & $\mathrm{B} 1, \mathrm{~B} 2, \mathrm{~A} 8$ \\
Elhanyagolható tényező típusú feltevés & $\mathrm{B} 3, \mathrm{C} 1, \mathrm{C} 2, \mathrm{~A} 6$ \\
Átmenetileg korlátozó, a leírást segítő feltevés & $\mathrm{A} 1, \mathrm{~A} 2, \mathrm{~A} 3, \mathrm{~A} 4, \mathrm{~A} 5, \mathrm{~A} 7, \mathrm{~A} 9, \mathrm{C} 3, \mathrm{C} 4$ \\
\hline
\end{tabular}

Forrás: saját szerkesztés. 
forgó melletti termelési módnál. A feltevést azonban Thünen feloldja, amikor az állati termékek földjáradékát egyedileg határozza meg.

Az elhanyagolható típusú feltevések nem gyakorolnak befolyást az elmélet kimenetelére, akkor sem, ha esetleg nem érvényesek a valóságban. Számos átmenetileg korlátozó feltevés is megfogalmazódik. Ezek nyilvánvalóan nem érvényesek a valóságban, de egyrészt könnyebbé teszik az elméleti leírást, másrészt később Thünen megvizsgálja az elmélet kimenetelére gyakorolt módosító szerepüket. Ha ez az utóbbi elméletépítési fázis elmaradna (ahogy az megszokott napjaink neoklasszikus fóáramának elméletépítésében), akkor a feltevések az elmélet érvényét korlátozó feltevések lennének, esetleg olyan mértékben, hogy az elmélet semmilyen körülmények között nem lenne alkalmazható.

Thünen a föld termékenységét a rozs hozamában definiálja. Alapesetben a maghozam nyolc egység, ami annak a rövidítése, hogy 100 négyzetvesszőnyi (vagyis 2172 négyzetméternyi) terület nyolc berlini véka (vagyis nagyjából 3,2 mázsa) rozst eredményez (Thünen 1930, 34., 52.). A föld azonos termékenységének feltevése megkönnyíti például a távolság hatásának kimutatását, de emellett a termékenység térbeli eltérésének befolyását is elemzi Thünen.

Thünen feltevéseit (Voraussetzungen, előfeltevések) a könyv 1966-os angol kiadásában hipotéziseknek fordították. Ez bírálható, mivel egy olyan állítás, amelyről megfogalmazása pillanatában tudható, hogy igaz-e vagy hamis, nem hipotézis. Hipotézis alatt - legalábbis a szó eredeti értelmében, amely eltér napjaink bizonytalanabb szóhasználatától - olyan sejtést értenek, amely tudományosan figyelemre méltó, érdekes, nem triviális és amelynek igazságát vagy hamisságát a további kutatásnak kell felderítenie. Thünen feltevéseinek nagy része biztosan, köztudottan, egyértelműen, nyilvánvalóan nem igaz a valóságban, amivel Thünen is tökéletesen tisztában volt.

\section{A termékek városi piaci árának és farmkapubeli árának a különbsége, valamint a szállítási költség kezelése}

Az elmélet lényegének ismertetése előtt röviden kitérek a szállítási költség kezelésére. A szállítási költség két részből tevődik össze: az üzemanyagköltségből, amely a lovak által elfogyasztott rozst jelenti, és a munkaköltségből, amely a szekerek megrakodásából, lerakodásából és vezetéséből áll. A következő számítások Thünen tellowi birtokának tapasztalati adatain alapulnak. A ló vontatta szekerek egy nap alatt 5 német mérföldet (kb. 38 kilométer) tudnak megtenni. 5 mérföldről a városba szállított egy szekérnyi rozs szállítása az oda- és visszaúttal együtt két napba telik, a szükséges munkaerő költsége ötéves átlagban 1,63 tallérnyi volt. A lovaknak a kétnapi úthoz szükséges rozsmennyisége 2,57 berlini vékányi. Egy szekér 29,35 berlini véka rozst tud szállítani. Az ötmérföldes oda- és visszaút így 1,63 tallérba és 2,57 véka rozsba kerül. Ha egy berlini véka 
rozs ára a városban másfél tallér, akkor a rozsért $(29,35$ - 2,57) × 1,5 = 40,17 tallér bruttó árbevételt realizál a termelő. Ebből a munkaerőköltséget levonva 38,54 tallér marad. Ezt elosztva a 29,35 véka rozzsal egy véka rozs farmkapubeli árára 1,313 tallér adódik. (Thünen 1930, 16-17.) A farmernek nem érné meg eladnia a rozst egy szállítási vállalkozónak ennél alacsonyabb árért. Bár Thünen a könyvben megemlíti a szállítási vállalkozó bekapcsolásának lehetőségét (Thünen 1930, 231.), de az ő idejében az volt a tipikus, hogy a betakarítást követően mindegyik gazdálkodó maga szállította terményeit.

Ugyanezt a számítást más távolságokra megismételve kapjuk a 3. táblázat adatait. Az eredmények tehát a következő feltevések mellett érvényesek: egy nap 5 német mérföldet képes megtenni a szekér, egy napi munkaerő költsége 1,63 tallér, egy véka rozs városi ára 1,5 tallér, a szállításra felhasznált négy ló vontatta szekér teherbírása 29,35 berlini véka, a lovak számára két napra szükséges takarmány 2,57 berlini véka. Thünen a könyvben később a városi ár változásának hatásával foglalkozik, a többi feltevés változatlan marad.

Ezt követően Thünen nagyon pontosan meghatározza egy szekér rakománynak a szállítási költségét a farmtól a városig és vissza a farmig. A szállítási költségben a munkaerő díja a távolsággal egyenesen arányos: 5 mérföldenként 1,63 tallér. A szállításhoz szükséges rozs mennyisége is egyenesen arányos a távolsággal: 5 mérföldenként 2,57 berlini véka. A rozs ára viszont a távolság növekedésével csökken, mivel a várostól távolabb olcsóbb a rozs. A több oldalnyi matematikai levezetést mellőzve a következő szállítási költségfüggvényhez jut el:

$$
\left(15925 x-199,5 x^{2}\right) /((182+x) \times(80-x)) \text { tallér, }
$$

ami csekély eltéréssel megegyezik a következő képlettel:

$$
199,5 x /(182+x) \text { tallér, }
$$

ahol $x$ a várostól való távolság mérföldben (Thünen 1930, 22.). Thünen a könyv-

3. táblázat: 1000 berlini véka rozs ára a távolság függvényében

\begin{tabular}{|c|c|c|}
\hline \multicolumn{2}{|c|}{ Távolság a várostól } & \multirow{2}{*}{$\begin{array}{c}\text { A rozs ára } \\
\text { (tallér) }\end{array}$} \\
\hline német mérföld & kilométer & \\
\hline 0 (a városban) & 0 & 1500 \\
\hline 5 & 38 & 1313 \\
\hline 10 & 75 & 1136 \\
\hline 15 & 113 & 968 \\
\hline 20 & 151 & 809 \\
\hline 25 & 188 & 656 \\
\hline 30 & 226 & 512 \\
\hline 35 & 264 & 374 \\
\hline 40 & 301 & 242 \\
\hline 45 & 339 & 116 \\
\hline 49,95 & 376 & 0 \\
\hline
\end{tabular}

The price of 1000 Berlin bushels rye, as a function of distance

Forrás: Thünen 1930, 17-18. alapján saját szerkesztés. 
ben ezzel a degresszív szállítási költséggel számol (2. ábra), ugyanakkor az ismertetések túlnyomó része lineáris szállítási költségről ír, ami mind a tapasztalatoknak, mind Thünennek ellentmond.

2. ábra: Egy szekérnyi rakomány átlagos szállítási költsége a távolság függvényében Average transportation cost of a cart as a function of distance

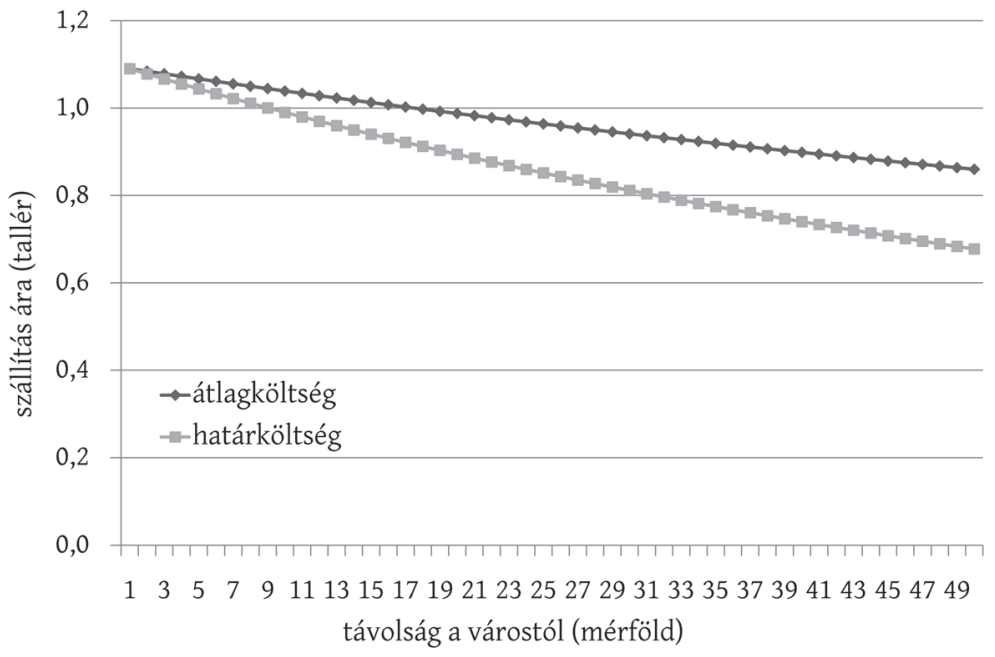

Forrás: Thünen $(1930,22$.$) alapján saját számítás és szerkesztés.$

\section{A földjáradék meghatározása}

Akár egy termelési rendszerről, akár egy egyedi termékről van szó, a földjáradék kiszámítása a következő módon történik:

Földjáradék = Piaci ár a városban - Termelési költség - Szállítási költség.

Thünen definíciója szerint a termelési költségekbe bele kell számítani a földbirtokba befektetett materiális eszközök (épületek, kerítések) értékével megegyező pénzösszeg kamatát. A földjáradék tehát kizárólagosan a földhöz mint termelési tényezőhöz tartozó jövedelem (Thünen 1930, 23.). Thünen hat oldalon keresztül bírálja Adam Smith földjáradék-koncepcióját, mivel Smith nem vonta le az ingatlanok értékének a kamatát a földbirtok jövedelméből. Így Smith földjáradékában a föld jövedelme és a tőke jövedelmének egy része megtévesztően vegyesen jelenik meg (Thünen 1930, 24-29.).

A földjáradékra a következő közvetlen tényezők hatnak:

1. A piactól való távolság.

2. Szállítási költség.

3. Egységnyi földterületre jutó termésátlag. 
4. A piaci ár.

5. Termelési egységköltség.

Ezek a tényezők egymással is kölcsönhatásban állnak. A termelési költséget négy (vagy ha a negyedik csoportot kettőnek tekintjük, öt) nagyobb csoportra osztotta Thünen:

1. Vetéssel kapcsolatos költségek.

2. Müvelési költségek.

3. Betakarítási költségek.

4.A Általános kultúrköltségek.

4.B Az épületek és kerítések értékével megegyező pénzösszeg kamata.

A vetéssel és műveléssel kapcsolatos költségek a terület nagyságával arányosak, így állandóak egy adott területegységen vagy birtokon. A betakarítási költségek a termés nagyságával arányosak, azzal egyenes arányban nőnek, hasonlóan az általános kultúrköltségekhez, amelyek közé egyetlen művelési ághoz sem hozzárendelhető tételek tartoznak, így az adminisztrációs költség, az épületek fenntartási, karbantartási költsége, a tanárokkal és lelkészekkel kapcsolatos kiadások, az üzemi tőke kamata, a szegények támogatása, az éjjeliőrök bére, az utak, hidak, árkok karbantartása, egyéb vegyes kiadások (Thünen 1930, 32-35.).

A kiadásokat kétféle elemre osztotta Thünen, a pénzügyi kiadásokra és a gabonakiadásokra, az utóbbit rozsban fejezte ki. Mint írja, az árpa és a zab könnyen átváltható rozsra értéke és tápanyaga alapján. A többi terméknél is térben állandó átváltási arányt tételezett fel, így rozsban ki tudta fejezni azokat. A vetéssel kapcsolatos költségeket kizárólag rozsban határozta meg. A többi költségelemnél a költségek egy része rozsban lép fel (például a lovak takarmánya), második része részben rozsban, részben pénzben (például a munkások bére), harmadik része kizárólag pénzben (például a só és a fémből készült eszközök ára). A rozsban és pénzben jelentkező költségek aránya tartományról tartományra, birtokról birtokra változhat. Thünen a számítások kiindulásaként a kiadások egynegyedét fejezi ki egy rögzített rozsár mellett pénzben, háromnegyedét rozsban. A rozsár változása a kiadások arányait megváltoztatja. (Thünen 1930, 37-40.)

Thünen számos termelési ágra és terményre, a változók (termésátlag, távolság és ár) számos eltérő paramétere mellett határozta meg a földjáradék nagyságát, többnyire 100 ezer négyzetvessző nagyságú birtokra. A levezetések rendkívül bonyolultak, olykor többoldalasak, mivel a különböző kiadások és bevételek egy része rozsban, más része pénzben jelentkezik. A rozsban kifejezett tételeket a számítások végén Thünen átváltja tallérra. A levezetések összetettsége miatt részleteiket nem ismertetem, csak azt a formulát, amellyel a hétéves vetésforgós műveléssel, egyheted ugarral, nyolc magos rozshozam mellett a földjáradék nagysága a távolság ( $x$ ) függvényében tallérban meghatározható:

$$
\frac{1168 \times(273-5,5 x)}{182+x}-641 \text { (Thünen 1930, 51.). }
$$


Az eredmények - együtt a háromnyomásos művelésre vonatkozó eredményekkel - a 4. táblázatban láthatók. 24,7 mérföldnél (186 kilométer) azonos a kétféle termelési mód földjáradéka, azon belül a vetésforgót, azon túl a háromnyomásos gazdálkodást célszerü alkalmazni.

Három további különböző termelési mód földjáradéka látható az 5. táblázatban. A kétféle kertgazdaságra vonatkozó számítások is mutatják, hogy Thünen rendszere sokkal összetettebb, mint amit az elmélet föbb vonalait

4. táblázat: A földjáradék nagysága (100 000 négyzetvessző nagyságú birtok, nyolc berlini véka terméshozam mellett, tallérban)

Value of ground rent (land of 100000 square rods, yields of 8 Berlin bushels, in thalers)

\begin{tabular}{ccc}
\hline Távolság a piactól, mérföld & \multicolumn{2}{c}{ Földjáradék } \\
\cline { 2 - 3 } & Vetésforgónál, egyheted ugarral & Háromnyomásos müvelésnél \\
\hline 0 & 1111 & 717 \\
5,0 & 892 & 587 \\
10,0 & 685 & 464 \\
15,0 & 488 & 347 \\
20,0 & 301 & 236 \\
24,7 & 134 & 134 \\
25,0 & 124 & 130 \\
28,6 & 0 & 55 \\
30,0 & -46 & 29 \\
\hline
\end{tabular}

Forrás: saját számítás Thünen 1930 alapján.

5. táblázat: A földjáradék alakulása a piactól való távolság függvényében tallérban

(100 000 négyzetvessző nagyságú birtok, a tűzifa egységára 21 tallér) Ground rents as a function of distance from the market in thalers (land of 100000 square rods, price of firewood is 21 thalers)

\begin{tabular}{|c|c|c|c|c|c|c|}
\hline \multirow{2}{*}{$\begin{array}{l}\text { Távolság } \\
\text { a piactól, } \\
\text { mérföld }\end{array}$} & \multicolumn{2}{|c|}{$\begin{array}{l}\text { Kertgazdaság (saját eloállitású } \\
\text { trágyát használva) }\end{array}$} & \multicolumn{2}{|c|}{$\begin{array}{c}\text { Kertgazdaság (vásárolt trágyát } \\
\text { használva) }\end{array}$} & \multicolumn{2}{|c|}{ Erdögazdaság } \\
\hline & Földjáradék & $\begin{array}{l}\text { A földjáradék } \\
\text { csökkenése }\end{array}$ & Földjáradék & $\begin{array}{l}\text { A földjáradék } \\
\text { csökkenése }\end{array}$ & Földjáradék & $\begin{array}{l}\text { A földjáradék } \\
\text { csökkenése }\end{array}$ \\
\hline 0 & 13411 & & 29808 & & 4548 & \\
\hline 1 & 11899 & -1512 & 24126 & -5682 & 4017 & -531 \\
\hline 2 & 10404 & -1495 & 18506 & -5620 & 3492 & -525 \\
\hline 3 & 8925 & -1479 & 12947 & -5559 & 2972 & -520 \\
\hline 4 & 7462 & -1463 & 7448 & -5499 & 2458 & -514 \\
\hline 5 & 6014 & -1448 & 2008 & -5440 & 1949 & -509 \\
\hline 6 & 4582 & -1432 & -3375 & -5383 & 1446 & -503 \\
\hline 7 & 3165 & -1417 & -8700 & -5326 & 948 & -498 \\
\hline 8 & 1763 & -1402 & -13970 & -5270 & 456 & -493 \\
\hline 9 & 375 & -1387 & -19184 & -5214 & -32 & -487 \\
\hline 10 & -998 & -1373 & -24344 & -5160 & -514 & -482 \\
\hline
\end{tabular}

Forrás: saját számítás Thünen 1930, 198., 208., 211. alapján. 
bemutató grafikus ábrázolás sugall. Az is jól látszik, hogy a távolsággal nem egyenes arányban csökken a földjáradék nagysága.

\section{A város körüli termelési zónák}

A földjáradékra befolyást gyakorló tényezők számbavételével a következő szempontok alapján lehet eldönteni két termény közül, hogy adott helyen melyiket érdemesebb termeszteni. A nagyobb termésátlagú termények egy hektárra jutó szállítási költsége nagyobb, mint a kisebb termésátlagúaké, ezért azonos ár és termelési költség mellett a nagyobb termésátlagú terményt elönyösebb a városhoz közelebb termelni. Azonos termésátlagú termények közül az alacsonyabb árú terménynél az árhoz viszonyított szállítási költség magasabb, ezért az alacsonyabb árú terményt érdemesebb a városhoz közelebb termelni. A romlandó terményeknél a szállítás időigénye által megszabott abszolút korlát is jelentkezik, függetlenül a termék súlyától és a szállitás költségétől, ezért azokat mindenképpen az abszolút távolságkorláton belül kell termelni.

Ugyanazt a terményt többnyire eltérő intenzitással, termelési technológiával is elő lehet állítani. Ez befolyásolja a termelési költséget és a termésátlagot is. A piachoz közelebb ugyanazon terménynél érdemes intenzívebb és nagyobb termésátlagot eredményező termelést folytatni, aminek nagyobb termelési költségét kompenzálja a szállítási költség csökkenése. Ezért a sok munkát, trágyát stb. igénylő termelés a piachoz közelebb található.

Eltérő terményeknél azonban nincs kapcsolat a piactól való távolság és a termelés intenzitása között, mert a termények ára, egységnyi földterületre jutó súlya és térfogata eltérő. Így ha az egységnyi földterületre jutó termelés a kicsi input ellenére is nagyon nagy, akkor azt a kevésbé intenzív termelés ellenére is a piachoz közel kell termelni a magas szállítási költség miatt. Erre példa a fakitermelés és a széna előállítása. Másrészt ha egy terméknek a térfogatsúlyra jutó értéke nagyon nagy, akkor azt a piactól távol lehet termelni. Erre példa a vajtermelés, a dohány termelése és az égetett szeszes italok eloállítása. Ezek a piactól nagyon távol is történhetnek, mert a szállítási költségük árukhoz és súlyukhoz viszonyítva is és más termékekhez képest is csekély.

A legnagyobb földjáradékot eredményező termékek termelése esetén a piaccal a középpontban a gazdálkodás koncentrikus körei alakulnak ki. Ezek Thünen idejében Thünen tellowi birtokának gazdasági adatai alapján számolva a 6. táblázatban látható módon alakultak. Az ötödik és hatodik zóna határvonalát Thünen számításaiból becsültem, a többi zóna határvonala Thünen számításaiból pontosan adódik.

A harmadiktól az ötödik zónáig terjedő gazdálkodási formákat ideáltipikusnak tekintette Thünen, amelyek a valóságban nagyon sok változatban fordulhatnak elő (Thünen 1930, 169-175.). E zónák közötti átmenet nem éles, hanem 
6. táblázat: Az elszigetelt állam mezőgazdasági termelési övezetei Thünen tellowi birtokának gazdasági adataival számolva, másfél talléros rozsár és nyolc magszemes terméshozam mellett Agricultural production zones in The isolated state, according to economic data of Thünen's estate in Tellow, with rye price of 1,5 thalers and yields of 8 grains

\begin{tabular}{|c|c|c|c|}
\hline $\begin{array}{l}\text { Övezet } \\
\text { sorszáma }\end{array}$ & Mezőgazdasági müvelési ág & $\begin{array}{l}\text { Az övezet külső } \\
\text { határának távolsága } \\
\text { a várostól }(\mathrm{km})\end{array}$ & $\begin{array}{c}\text { Az övezet területe } \\
\left(\mathrm{km}^{2}\right)\end{array}$ \\
\hline 1 & Kertgazdaság, tejtermelés. & 30 & 2827 \\
\hline 2 & Erdőgazdaság (tűzifa és építőanyag). & 53 & 5997 \\
\hline 3 & $\begin{array}{l}\text { Intenzív szántóföldi termelés hatéves } \\
\text { vetésforgóval. Nincs ugar, a termények: kéthatod } \\
\text { rozs, egyhatod burgonya, lóhere, árpa, bükköny; } \\
\text { istállózó állattartás. }\end{array}$ & 71 & 7012 \\
\hline 4 & $\begin{array}{l}\text { Szántóföldi termelés hétéves vetésforgóval. A } \\
\text { terület egyhetede ugar, háromhetede legelő, } \\
\text { egyhetedén rozs, egyhetedén árpa, egyhetedén } \\
\text { zab termelése. }\end{array}$ & 186 & 92850 \\
\hline 5 & $\begin{array}{l}\text { Háromnyomásos gazdálkodás, egyharmad } \\
\text { szántóföldi termelés, egyharmad legeltetés, } \\
\text { egyharmad ugarolás. }\end{array}$ & 237 & 67774 \\
\hline 6 & $\begin{array}{l}\text { Legeltető állattenyésztés, mellette szántóföldi } \\
\text { termelés saját fogyasztásra, dohány, pálinkafózés. }\end{array}$ & 376 & 267686 \\
\hline 7 & Vadászat, önellátás & Végtelen & Végtelen \\
\hline
\end{tabular}

Forrás: saját szerkesztés Thünen 1930 alapján.

fokozatos. A negyedik zóna külső széle alig különböztethető meg az ötödik zóna belső szélétől, a negyedik zónán belül is fokozatosan csökken a munkafelhasználás és növekszik az ugar aránya. A negyedik zónára az északnémet szóhasználat szerint Thünen a Koppelwirtschaft kifejezést használja, a terminusnak pontos magyar (és angol) megfelelője nincs. A Pallas nagylexikon legelőváltó gazdálkodásnak nevezi, de a legelőváltó gazdálkodást számos kontextusban, kevésbé intenzív művelési formákra is alkalmazzák. Varga Attila (2003) a „vetésforgó ugarral”, Kozma Gábor (2003) a „kevésbé intenzív gazdálkodás”, Lengyel Imre és Rechnitzer János (2004) a „szántóföldi termelés ugarolással” kifejezést használja.

A hatodik zóna területe a legnagyobb, népsürüsége viszont jóval kisebb az első zóna népsűrűségénél. Egy olyan birtok, amely a város közelében 30 családot ellát munkával és élelemmel, itt alig három családnak biztosít megélhetést (Thünen 1930, 261.). Ebben az övezetben nevelik és hizlalják a szarvasmarhát, a belsőbb övezetek is innen szerzik be a fiatal marhákat. A marhák saját lábukon szállíthatók, minimális költség mellett (ennek nagyságát Thünen nem határozza meg). Gabonát gazdaságosan már nem lehet innen a városba szállítani, így azt csak saját szükségletre és a szállításhoz termelnek. A gabonából pálinkát készíteni azonban itt lehet a leggazdaságosabban, mivel a rozs ára itt töredéke a városi 
rozsárnak, a nominális bér pedig fele-harmada a városinak. A pálinka súlya egynegyede annak a rozsnak, amelyből készült, értéke viszont nagyobb, így árához és súlyához viszonyított szállítási költsége jóval kisebb a rozsnál. Ha a pálinkafózést csak a városban engedélyezik, akkor - mint Thünen rámutat - az a nemzeti jövedelem csökkenéséhez vezet: nagyobb szállítási költségekhez (nemcsak a rozst kell a városba szállítani, hanem a tüzifát is) és nagyobb munkaerőköltségekhez. Thünen nem tökéletes versenyről beszél, mivel a tökéletes verseny neoklasszikus koncepciója akkor még meg sem született, hanem a jogi kötöttségektől mentes helyzetet hasonlítja össze a jogilag korlátozott helyzet jóléti veszteségével (Thünen 1930, 275-276.). Thünen megemlíti, hogy néhány évszázada még egész Mecklenburgban legeltető állattenyésztés lehetett, majd a népesség növekedése vezetett az egyre intenzívebb művelési ágak megjelenéséhez.

A legeltető állattenyésztés övezetén túl néhány vadász él szétszórva. Az egyetlen gazdasági kapcsolatot a város és az itt élő vadászok között a prémkereskedelem jelenti (Thünen 1930, 262.).

A 3. táblázat kapcsán tárgyalt maximális távolság, a 49,95 mérföld (376,2 kilométer) egyben az elszigetelt állam adott ár és szállitási költség mellett földjáradékot hozó területének nagyságát is mutatja. Thünen az állam grafikus ábrázolásáról úgy ír, hogy az nem szükséges az elmélet megértéséhez, de az eredmények könnyű és kényelmes áttekintését biztosítja. Az ábrázolás során a legkülső gyürü, a legeltető állattenyésztés határát a helytakarékosság miatt húzta meg 40 mérföldnél (301,3 kilométer) a korábban bemutatott és kiszámolt 50 mérföld helyett (Thünen 1930, 386.). A legkülső zóna nagysága így Thünen eredeti ábráján és annak reprodukcióin megtévesztő. Az ábra későbbi közlései ritkán jelenítik meg a méretarányt, a külső zóna 10 mérfölddel nagyobb voltát szintén nem korrigálják. A 3. ábra a zónákat az eredeti méretarány mellett mutatja.

Ezek a gyűrűk a gazdaságilag optimális helyzetet jelentik, vagyis például ha a legbelső gyürüben kertgazdaság helyett legeltető állattenyésztést folytatnának, akkor nem vennék figyelembe a föld helyzetéből (a piactól való távolságából) fakadó sajátosságokat és alacsonyabb jövedelemhez jutnának. Ugyanez a fordított esetre is igaz, a várostól távoli piacra termelő kertgazdaság és tejtermelés nem racionális, mert a szállítás ideje alatt a zöldség és a tej megromolna. Ahogy Thünen írja, ha a hatéves vagy hétéves vetésforgót bevezetnék egy olyan birtokon, amely a háromnyomásos gazdálkodás zónájában található, annak idővel nyom nélkül el kellene tünnie. A fordított eset, a háromnyomásos művelés bevezetése a vetésforgó övezetében sem fenntartható, de egy ilyen kísérlet annyira kevésbé csábító, a hátrányai annyira szembetűnőek, hogy gyakran nem fordulhatna elő (Thünen 1930, 262-263.).

Az elméletnek ugyanakkor nem a konkrét, történetileg meghatározott formája az érdekes, hanem az elemzés módszertana. Ha az elszigetelt állam városának piacát behelyettesítjük bármilyen piaccal, és az egyes termények által elérhető földjáradékot a vizsgált változók függvényében meghatározzuk, elvileg ugyanezt az eredményt kapjuk, csak az adott helyre és időpontra jellemző, más 
konkrét formában. A lényeges különbséget az jelenti, hogy a valóságban többnyire nem egyetlen piachely van, hanem az egyes termények egymással nem pontosan megegyező felvásárlási pontjainak térbeli hálózatával kell számolni. A piacoktól való költségtávolság és a termékek differenciáltsága azonban ebben a bonyolultabb esetben is ugyanúgy meghatározza azt, hogy milyen terméket hol és milyen intenzitással érdemes termelni. Egyes bírálatok szerint a szállítási ágazat fejlettsége és ezzel együtt a távolság szerepének csökkenése miatt az elmélet napjainkban nem túlságosan releváns. Ez azért félreértés, mert a szállítási ágazat fejlődése nem egységesen hat minden egyes termékre. A mezőgazdasági termények egy részénél a szállítási tényező szerepe hasonlóan fontos, mint Thünen idejében volt.

A 3. ábra konkrét formájának esetlegességét Thünen számos további számítása bizonyítja. Egy példát bemutatva, az optimális termelési intenzitás a szállítási költség és a piaci ár függvényében határozható meg. Kétféle termelési mód mellett (egyhetednyi ugarral és háromnyomásos ugaroló gazdálkodással) a földjáradék nagysága a rozs piaci árának függvényében a 7. táblázat szerint alakul a piactól 5 mérföld távolságra. Az eredményekből látszik, hogy a költségesebb, intenzívebb termelési rendszer mellett a földjáradék nagysága érzékenyebben reagál a piaci ár változásaira. Ennek az az oka, hogy a nagyobb terméseredmény nagyobb teljes szállítási költséget eredményez, ami a földjáradék egyenesének nagyobb meredekségéhez vezet. Bár az adott példában Thünen kétféle termelési

3. ábra: Az Elszigetelt állam mezőgazdasági termelési övezetei Thünen tellowi birtoka gazdasági adatai alapján számolva, másfél talléros rozsár és nyolc magszemes terméshozam mellett

(az övezet sorszámainak magyarázatát lásd a 6. táblázatban)

Land use in the Isolated state according to economic data of Thünen's estate in Tellow (with rye price of 1,5 thalers and yields of 8 grains)

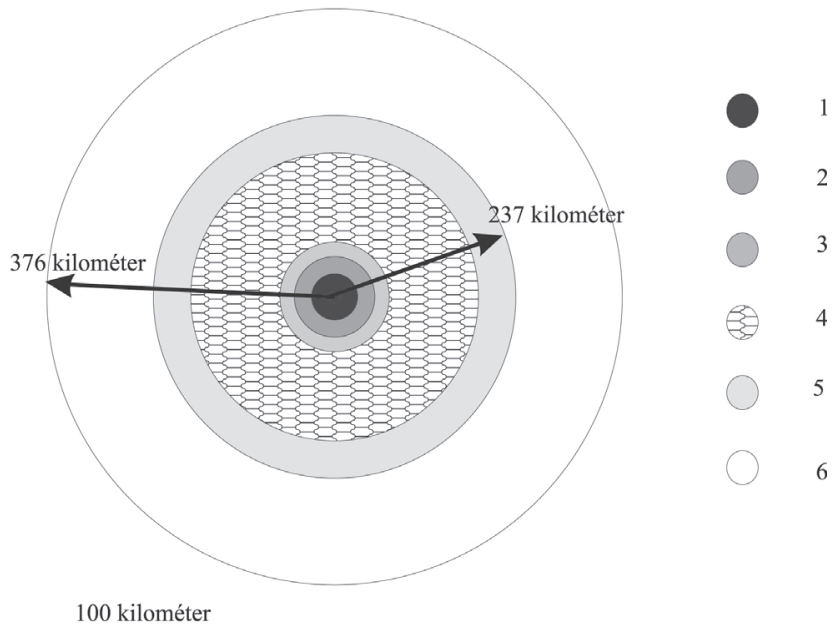

Forrás: saját szerkesztés Thünen (1930) alapján. 
7. táblázat: A földjáradék nagysága a rozs piaci árának függvényében a piactól öt mérföld távolságra, tíz véka rozshozam mellett (100 000 négyzetvessző területű birtok)

Value of ground rent as a function of the market price of rye, in 5 miles from the market, at yields of 10 bushels (land of 100000 square rods)

\begin{tabular}{lcc}
\hline Piaci ár (tallér) & Vetésforgó egyhetednyi ugarral & Szántóföldi termelés egyharmadnyi ugarral \\
\hline 1,5 & 1818 & 1119 \\
1 & 963 & 619 \\
0,516 & 135 & 135 \\
0,5 & 108 & 119 \\
0,437 & 0 & 56 \\
\hline
\end{tabular}

Forrás: Thünen 1930, 121-122. alapján saját szerkesztés.

rendszert hasonlított össze, tisztában volt vele, hogy közöttük nincs éles határvonal, az intenzitás csökkenése valójában nem ugrásszerű, hanem a távolság függvényében fokozatos. A földjáradék nagysága azért tér el a 4. táblázat öt mérföldes adataitól, mert Thünen itt attól eltérő, nagyobb terméshozammal számolt.

\section{Az egyedi farmergazdaságok körül kialakuló termelési zónák}

Thünen munkájának az ismertetésekből szinte teljesen kimaradó, de mégis nagyon lényeges mozzanata, hogy az egyedi farmgazdaság körül a központi városhoz hasonló termelési gyürűk, zónák alakulnak ki. Ezzel a kérdéssel az első kötet 11. fejezetében foglalkozik, amelynek címe: A szántóföld farmtól való távolságának befolyása a munkaköltségekre (Thünen 1930, 98-104.). Valószerütlen és irreális lenne feltételezni a termelési zónák tökéletes homogenitását és azt, hogy a farmerek az esetleg többnapi járóföldre lévő városi piacon szerzik be napi tejszükségletüket vagy ott vásárolják zöldségfogyasztásuk forrását. Ezeket az igényeket a saját fogyasztásra termelés keretében elégítik ki az összes termelési zónában. A termelő termelési tervét a városi piac által meghatározott, a farm központjában attól a szállítási költségekkel eltérő termelői ár alapján alakítja ki. Természetesen a piaci ár és a szállítási költség is előrebecsült, a múltbeli tapasztalatok alapján feltételezett. A farm közelében munkaintenzív és nagy súlyú termékek termelése folyik, a farmtól távolodva pedig egyre extenzívebb a termelés.

A farmtól való távolság hatását Thünen úgy határozta meg, hogy felosztotta a szántóföldi termeléshez szükséges munkaműveleteket aszerint, hogy mennyire mozgásigényesek. Például a cséplés egyáltalán nem mozgásigényes, mert a farmon egy helyben lehet végezni, az aratás, a vetés, a trágya szétszórása mozgásigényes. Thünen tellowi birtoka 70000 négyzetvessző nagyságú volt, az udvarház szántóföldtől való átlagos távolsága 210 vessző. Ennek meghatározását, ami egy pontnak egy síkidomtól való átlagos távolságának kiszámítását igényli, érdekesen és módszertanilag teljesen megalapozottan tette Thünen. A költségek között elkülönítette a szántóföldi mozgásból fakadó, vagyis a szántó- 
föld térbeli kiterjedésétől függő költségeket a térfüggetlen költségektől. Így meg tudta határozni, hogy a 210 vesszőnyi átlagtávolság mekkora térköltséggel jár, majd ezt követően a szántóföld átlagtávolsága függvényében ki tudta számolni a földjáradék alakulását. Számításainak végeredménye a 8. táblázatban látható. Ennek megfelelően a farmtól nagyjából átlagosan 4,5 kilométerre fekvő termékeny szántóföld sem eredményez már földjáradékot, vagyis ha túl nagy a farm vagy a földbirtok egy része vagy egésze valamiért túl messze fekszik a farmtól, akkor a távoli területek megműveletlenül maradnak, vagy egy másik, a parcellához közelebbi farmernek bérbe adva lesznek megművelve.

Az egzakt számításoknál azonban fontosabbak a számításokból levonható általános összefüggések, a mikroszintű birtokelrendeződés, a birtokok és az udvarházak relatív helyzetének fontossága. A farmok optimális nagysága függ a piactól való távolságuktól, bár ez nem jelenti automatikusan, hogy a piactól távolabbi farmok szükségszerűen nagyobbak is lesznek és kevésbé intenzív termelést folytatnak. A mecklenburgi tanyák elhelyezkedését Thünen abszurdnak tartja, a korai megtelepülés történeti emlékművének, amikor a tavak, folyók, patakok partján épült fel az udvarházak többsége. Alig van olyan birtok, amelynek az épületei a középpontban fekszenek, ezért a birtoktestek lekerekítésével, cseréjével kölcsönösen jól járhatnának a cserében részt vevők. Egy ilyen rendezéssel és a tanyáknak a birtoktestek közepébe kerülésével Thünen számításai szerint néhány millió tallér megtakarítást lehetne elérni. A rendezést gátolják a szubjektív tényezők: az örökölt birtokhoz való ragaszkodás és a saját terület túlértékelése. Önmagában azonban ez nem lenne elég ok. Három további gátló

8. táblázat: A tellowi birtok földjáradékának nagysága a farmtól való átlagtávolság és a termésátlag függvényében

Ground rents of the Tellow estate, as a function of the mean distance from the farm and the yield

\begin{tabular}{|c|c|c|c|c|c|}
\hline \multirow{2}{*}{$\begin{array}{c}\text { A szántóföld farmtól való } \\
\text { átlagtávolsága }\end{array}$} & \multicolumn{5}{|c|}{ A gabona maghozama } \\
\hline & 10 egység & 9 egység & 8 egység & 7 egység & 6 egység \\
\hline 0 & 1187 & 975 & 763 & 551 & 339 \\
\hline $\begin{array}{l}210 \text { vesszőnként ennyivel } \\
\text { változik a földjáradék }\end{array}$ & (233) & (215) & (197) & (179) & (161) \\
\hline 210 vessző & 954 & 760 & 566 & 372 & 178 \\
\hline 420 vessző & 721 & 545 & 369 & 193 & 17 \\
\hline 443 vessző & - & - & - & - & 0 \\
\hline 630 vessző & 488 & 330 & 172 & 14 & \\
\hline 646 vessző & - & - & - & 0 & \\
\hline 813 vessző & - & - & 0 & & \\
\hline 840 vessző & 255 & 115 & & & \\
\hline 952 vessző & - & 0 & & & \\
\hline 1050 vessző & 22 & & & & \\
\hline 1070 vessző & 0 & & & & \\
\hline
\end{tabular}

Forrás: Thünen 1930, 104. 
tényező a birtok vagy birtokrész eladása után fizetendő adó, ami a csere esetén is fizetendő, sőt, akkor duplázódik a mértéke. A második tételt a különböző adminisztratív költségek jelentik: a birtokok felmérése, az adókataszterben való átírás költségei. Harmadrészt a birtokokon lévő adósságok is megnehezítik a cserét. (Thünen 1930, 108-113.) Mindezekkel az adminisztratív és gazdasági hátráltató tényezőkkel napjaink magyarországi föld- és ingatlanforgalmát is jellemezhette volna Thünen.

\section{Az elmélet és a valóság összehasonlítása Thünennél}

Thünen a második kiadás előszavában arra inti az olvasót, hogy ne rettenjen meg a valóságtól eltérő feltevésektől és ne tekintse azokat céltalannak. Ezek a feltevések szükségesek szerinte ahhoz, hogy világos képet kapjunk egy olyan hatásról, amely a valóságban ténylegesen létezik, de sok más tényező együtthatása miatt a valóságban zavartalan módon nem megfigyelheto”. „A szemlélődésnek ez a formája életemben már olyan sokszor fényt és világosságot adott és olyan kiterjedten alkalmazhatónak tünik számomra, hogy ezt tartom a legfontosabbnak ebben az egész írásban." (Thünen 1930,4.)

Az Elszigetelt állam első kötetében folyamatosan elemzi a különféle tényezők hatását, és egyfolytában hasonlítja az elméletet a valósághoz, ezért itt csak egy rövid és nem teljes körü áttekintő listát tudok adni a figyelembe vett különbségek egy részéről:

1. A valóságban nincs azonos termékenységü föld. Az eltérő termékenység hatását Thünen úgy vizsgálta, hogy a piactól való távolságot és a termék árát rögzítette, a földterület termékenységét változtatta. Ha a városban egy véka rozs ára 1 tallér, akkor számításai szerint a terméshozam függvényében a 9. táblázatban látható módon alakul a piactól 5 mérföldre lévő birtok földjáradéka. Thünen megállapítja, hogy adott rögzített piaci ár mellett a termékenyebb föld az intenzívebb hétéves vetésforgós müveléssel, a terméketlenebb föld a kevésbé intenzív háromnyomásos ugaroló müveléssel eredményez nagyobb földjáradékot.

2. Nincs olyan nagyváros, amelynek ne lenne folyója. A folyó mentén a olcsóbb szállítási költség miatt a termelési övezetek alakja megnyúlik. Thünen feltételezése szerint a vízi szállítás költsége egytizede a szárazföldinek, így egy folyóparton fekvő, a folyón a várostól 100 mérföldre lévő birtok a költségtérben ugyanolyan messze van a piactól, mint a várostól 10 mérföldre és a folyótól is legalább 10 mérföldre fekvő birtok. A várostól 10 mérföldre, de a folyótól kevesebb, mint 10 mérföldre fekvő birtoknál a kétféle szállítási mód együttes költségével lehet számolni. Thünen így már önmagában feloldotta a földrajzi távolsággal arányos szállítási költség feltevését. Ennek a feltevésnek a feloldása ugyanakkor 
9. táblázat A földjáradék nagysága a föld termékenységének a függvényében (a piactól való távolság 5 mérföld, egy véka rozs ára 1 tallér, a földterület nagysága 100 ezer négyzetvessző)

Ground rents as a function of productivity of land (distance from the market is 5 miles, price of one bushel rye is 1 thaler, land of 100000 square rods)

\begin{tabular}{ccc}
\hline Termékenység: rozshozam & \multicolumn{2}{c}{ Földjáradék, tallér } \\
\cline { 2 - 3 } 100 négyzetvesszőnként & Hétéves vetésforgó & Háromnyomásos gazdálkodás \\
\hline 10 véka & 963 & 619 \\
9 véka & 745 & 494 \\
8 véka & 527 & 369 \\
7 véka & 309 & 244 \\
6 véka & 91 & 119 \\
5 véka & -127 & -6 \\
\hline
\end{tabular}

Forrás: Thünen 1930, 124. alapján saját számítás és szerkesztés.

nem annyira érdekes, mert ha eleve a költségtérben értelmezzük a kialakuló zónákat, akkor érvényes marad a koncentrikus körök rendszere. Ha a földrajzi térben, akkor viszont nemcsak a vízi szállítás miatt nem érvényes, hanem a szállítás földrajzi akadályai és a nem egyenletes úthálózat miatt sem.

3. Nemcsak a vízi szállítást vezeti be könyvében, hanem foglalkozik a jobb országutak és a vasúti szállítás lehetőségével is. A vasúti szállítás olyan mértékben növeli meg az állam területét, hogy ez az állam északi és déli részének nagyon eltérő klímájához vezet (Thünen 1930, 424.). Ez számos további kérdés vizsgálatához vezet Thünen szerint: a legeltetési idő változásának hatása a szarvasmarha-tenyésztésre, a területileg eltérő termények, a munkabér, a munkaképesség változása, a terméseredmény területi különbségei.

4. Foglalkozik a hegyes vidékek helyzetével (mint Szilézia, Morvaország, Szászország), ahol csak a völgyekben lehetséges a szántóföldi termelés, egyébként csak a legeltetésre nyílik mód (Thünen 1930, 174-175.). Elméletileg nem tud választ adni arra, hogyan történik a háromnyomásos gazdaság és a vetésforgó közötti átmenet ilyen térségekben.

5. Minden államnak több városa, ezzel együtt több piachelye van. A kisvárosok körül ugyanúgy kialakulnak a termelés zónái, mint az állam nagy központi városa körül. Ezek a kisvárosok körüli és a kisvárosoknak termelő területek a föváros számára ugyanúgy elvesznek, mintha terméketlen pusztaságok lennének. Ez olyan hatást gyakorol a fóváros körüli zónákra, hogy (változatlan kereslet mellett) azok kiterjedését megnöveli. A kisvárosok piacának árai azonban más módon határozódnak meg, mint a föváros piacának ára, mivel a kisvárosok körüli termelők választhatnak aközött, hogy melyik városba szállítják termékeiket. A fóvárosi ár és a fơvárosba szállítás költségének a különbözeténél nem lehet kisebb a kisvárosi ár és a kisvárosba szállítás különbözete. A kisvárosok 
piaci árát tehát a főváros piaci ára határozza meg, illetve a két ár közötti függés kölcsönös, de a viszony aszimmetrikus, mert a kisváros kisebb piacmérete miatt kevésbé hat a nagyvárosi piacra, mint viszont. A grafikus ábrázolásban csak egy kisebb várost jelentet meg Thünen, de a szöveges elemzésben kisvárosokról ír. (Thünen 1930, 272-273.)

6. Az adók hatását Thünen az első kötet külön részében is tárgyalja, valamint számos más helyen elszórtan. Megállapítja, hogy a munkát és tőkét terhelő adóknak nagyobb a relatív hatása a várostól távolabb fekvo", valamint az alacsonyabb termékenységü földdel rendelkező birtokokra. Ezeknek bár kevesebb adót kell fizetniük, de földjáradékuk ennél nagyobb mértékben kisebb, ezért a tőke- és munkaigényes tevékenységek feladására kényszerülhetnek.

7. Thünen feloldja az egy politikai állam feltevését, és az elszigetelt állam területét jogilag két különböző államra osztja, egy gazdagabbra és egy szegényebbre, hogy így vizsgálja a szállítás jogi akadályait, a vámokat és a kereskedelmi korlátozásokat. Ezek a jogi eszközök ugrásszerű változásokat eredményeznek a termelési költségekben és a termelési zónákban. Az európai országok különbségei (London környékétől a Volgán túli területekig) Thünen szerint még nagyobbak is az elszigetelt állam termelési zónáinak különbségeinél. Ahogyan az elszigetelt államnál a kereskedelem korlátozásai jóléti veszteségeket okoznak a gazdagabb és szegényebb államoknak egyaránt, úgy az akkori Európában jellemző kereskedelmi korlátozások is hátrányosan érintik az összes országot. (Thünen 1930, 318-323.)

8. A földjáradék számos okból lehet nulla az elszigetelt állam 50 mérföldes gazdaságilag hasznosított határán belül is. Ezek közé tartozik a rossz talajminőség, a farmtól való túl nagy távolság, a talaj mély fekvése és rossz vízelvezetése, a terület erdővel körülölelt és ezért nehezen megközelíthető volta. A valóságban minden birtok jó és rossz adottságú talajok, könnyebben és nehezebben művelhető részek keverékéből áll. (Thünen 1930, 329.)

Röviden összefoglalva a tárgyalt fontosabb módosító tényezők hatását, mindezek az alapmodell koncentrikus körös földhasználatához képest a valóságban sokkal komplexebb térhasználatot eredményeznek. Ez azonban nem érvényteleníti a távolság gazdálkodásra gyakorolt hatását, csak bonyolultabbá teszi az összefüggéseket. A térgazdaságtan örök érvényủ alapelve marad a piactól való távolság és a szállítási költségek befolyása a térhasználatra.

\section{Összegzés}

Thünen könyve rendkívül gondolatgazdag. Jelen tanulmány terjedelmi okok miatt ennek a gazdagságnak csak kis részét tudta megjeleníteni, de talán ennyi- 
ből is érezhető, hogy eredetisége ellenére a mezőgazdasági térhasználat elméletének első, thüneni prezentálása annyira érettre és tökéletesre sikerült, hogy a későbbi szerzők csak az elmélet alkalmazott részeit tudták kiegészíteni (egy adott időszakra, térségre, termékekre, szállítási körülményekre vonatkozó részletekkel), valamint az érdemi mondanivalót nem érintő formai változtatásokat tudtak javasolni. Azok a tanulmányok vagy ismertetések, amelyek nem Thünen eredeti művét veszik alapul, hanem Thünen müvének néhány oldalas leegyszerűsített értelmezéseit, ettől eltérő következtetésre juthatnak. Ezek elterjedtsége indokolja a visszatérést az eredeti műhöz.

\section{Jegyzetek}

1 A tanulmány megírását az OTKA (K 81598) támogatta.

2 A német kiadások letölthetők innen: http://archive.org. Thünen életéről lásd Hans Schumacher szintén innen letölthető, 1868-ban megjelent könyvét: Johann Heinrich von Thünen. Ein Forscherleben (Schumacher 1868).

3 Az új gazdaságföldrajzban a térbeliség endogén kezelésének sajátosságáról olvashatunk Krugmanra hivatkozva például Lengyel Imrénél (Lengyel 2003, 39.; Lengyel 2010, 17.). Krugmannál nem találtam az endogén-exogén megkülönböztetésre utalást, Krugmannak a korábbi regionális gazdaságtani elméletekre vonatkozó, véleményem szerint megalapozatlan bírálata más tényezőkön alapul. Gál Zoltán az endogenitás egyedisége kapcsán úgy fogalmaz, hogy „az új gazdaságföldrajz az első elmélet, amely a hagyományos közgazdasági kategóriák alapján endogenizálta a földrajzi adottságokat, megpróbálja azokat a gazdaságelméletbe integrálni, sőt ezen túlmenően a gazdasági folyamatok területi koncentrálódásának hatásait is modellezi." (Gál 2010,151.)

4 A vessző hossza tartományonként, időszakonként és a mért objektumtól függően is kicsit változó volt, földterület mérésekor 4,66 méterrel egyenlő.

5 „Az elszigetelt állam felépítésének módjából már adódik, hogy a teljes területre a klíma egyformasága volt feltételezve" (Thünen 1930, 424.).

\section{Irodalom}

Fujita, M. (2011): Thünen and the new economic geography. RIETI Discussion Paper Series, 11-E-074

Gál Z. (2010): Pénzügyi piacok a globális térben. Akadémiai Kiadó, Budapest

Kozma G. (2003): Regionális gazdaságtan. Kossuth Egyetemi Kiadó, Debrecen

Krugman, P. (2003): Földrajz és kereskedelem. Nemzeti Tankönyvkiadó, Budapest

Lengyel I. (2003): Verseny és területi fejlődés: térségek versenyképessége Magyarországon. JATEPress, Szeged

Lengyel I. (2010): A regionális tudomány „térnyerése”: Reális esélyek avagy csalfa délibábok? Tér és Társadalom, 3., 11-40.

Lengyel I., Rechnitzer J. (2004): Regionális gazdaságtan. Dialóg Campus Kiadó, Budapest, Pécs

Melamid, A. (1955): Some applications of Thünen's model in regional analysis of economic growth. Papers and Proceedings of the Regional Science Association, 1., 1-5.

Peters, G. H. (1967): Book review: von Thunen's Isolated state. Urban Studies, 4., 193-194.

Petersen, A. (1944): Thünens isolierter Staat. Verlag Paul Parey, Berlin 
Samuelson, P. A. (1983): Thünen at two hundred. Journal of Economic Literature, 4., 1468-1488.

Schumacher, H. (1868): Johann Heinrich von Thünen. Ein Forscherleben. Leopold's UniversitätsBuchhandlung, Rostock

Schumpeter, J. A. (1954): History of economic analysis. Oxford University Press, New York

Thünen, J. H. von (1930): Der isolierte Staat. Verlag von Gustav Fischer, Jena

Varga A. (2003): Thünen és az „új gazdaságföldrajz” térgazdaságtana. In: Barancsuk J., Oroszi S., Varga A. (szerk.): Tanulmányok Zinhober Ferenc professzor emlékére. Pécsi Egyetemi Könyvkiadó, Pécs, 87-98.

Waentig, H. (1930): Thünen. (Bevezetés a Der isolierte Staathoz.) Verlag von Gustav Fischer, Jena, III-XV.

http://www.emecklenburg.de/Mecklenburg/l15.php?messen 